Journal of Social Sciences 4 (4): 299-307, 2008

ISSN 1549-3652

(C) 2008 Science Publications

\title{
The Link between Modification Flexibility and Organizational Objectives: An Empirical Study on Jordanian Manufacturing Companies
}

\author{
${ }^{1}$ Abdulkareem S. Awwad and ${ }^{1}$ Soud M. Almahamid \\ ${ }^{1}$ Department of Business Administration, Faculty of Business Administration and Economics, \\ Al-Hussein Bin Talal University, Ma'an P.O. Box 20, Jordan
}

\begin{abstract}
Problem statement: The motivation for this study is determining the extent that modification flexibility affects positively the achievement of strategic and operational objectives in the context of Jordanian manufacturing companies. It addresses the relationship between modification flexibility and organizational objectives. Approach: to tackle the problem statement, the positivistic paradigm was adopted and therefore, a cross-sectional survey employing a questionnaire method of data collection was used. Director, Vice-President, Operations or Production Manager, and Marketing Manager in the Jordanian Manufacturing Companies classified in Amman Stock Exchange Market were targeted by this study. For the purpose of data analysis, the research utilized descriptive and analytical statistics using simple regression analysis. Results: The results of data analysis indicated that the achievement of strategic and operational objectives is affected by the construct of modification flexibility. Conclusions/Recommendations: The findings of this research have many practical implications for managers such as: encouraging managers to use modification flexibility in planning, setting, and achieving the organizational objectives and encouraging them to use modification flexibility in planning and implementing the operations strategy of a firm in the short and long run. The study also proposed several directions for future research such as conducting more empirical studies about the role of modification flexibility on gaining the competitive advantage of a firm and improving its performance.
\end{abstract}

Key words: Flexibility, modification flexibility, strategic objective, operational objectives

\section{INTRODUCTION}

It is heavily believed that flexibility plays a significant and important role in planning, implementing and controlling the both of manufacturing and operations strategy. Therefore, flexibility is considered as a strategic weapon in the arsenal of any manufacturing firm. It enables organizations to respond effectively and efficiently to changing circumstances, particularly, when dealing with uncertain business environments that are characterized by rapid changes, shorter product life cycles and increasing product variety. Therefore, manufacturing flexibility is emerging as a competitive weapon that should be considered as a result for many drivers of flexibility such as (the need to change product design, the need to shorten product life cycle, the need to adopt customization strategy and the need to cope with uncertainty such as uncertainly about machines, technology, customers' requirement and expectations). Moreover, flexibility is considered as one the competitive priorities that manufacturing companies should consider them when planning their operations and manufacturing strategy. These competitive priorities include: Cost, quality, delivery, productivity and flexibility.

Research questions: The central question of this study is: To what extent does the modification flexibility affect positively the achievement of organizational objectives in the Jordanian manufacturing companies?

Research objectives: Considering the research question mentioned above, the research objectives can be summarized as follows:

- To examine the influence of modification flexibility on the achievement of organizational objectives in the Jordanian manufacturing companies.

- To provide a better understanding for the link between modification flexibility and organizational objectives.

Theoretical framework and previous studies: Flexibility is characterized ${ }_{34}$ as a complex and multidimensional construct ${ }^{\text {[3] }}$.

Corresponding Author: Abdulkareem S. Awwad, Department of Business Administration, Faculty of Business Administration and Economics, P.O. Box 20, Al-Hussein Bin Talal University, Jordan-Ma'an. 
Table 1: Classifications of flexibility

\begin{tabular}{|c|c|}
\hline Author(s)/ Researcher(s) & Flexibility (classification) dimensions \\
\hline Buzacott $^{[4]}$ & $\begin{array}{l}\text { Job flexibility is the ability of the system to cope with changes in jobs to be processed by the system. } \\
\text { Machine flexibility is the ability of the system to cope with changes and disturbances at the machine and work } \\
\text { stations. }\end{array}$ \\
\hline Sethi and Sethi ${ }^{[34]}$ & $\begin{array}{l}\text { Basic flexibilities (machine, material handling, operation) } \\
\text { System flexibilities (process, routing, product, volume, expansion) } \\
\text { Aggregate flexibilities (program, production, market) }\end{array}$ \\
\hline Gupta and Somers $^{[15]}$ & $\begin{array}{l}\text { Structural flexibility "flexibility of the technology and human resources } \\
\text { Infrastructural flexibility "flexibility of the systems, the procedures and the practices which integrate and co- } \\
\text { ordinate the operations }\end{array}$ \\
\hline Chen et al. ${ }^{[8]}$ & $\begin{array}{l}\text { Production flexibility, which includes the following types of flexibility: (machine flexibility, process } \\
\text { flexibility, routing flexibility, manpower flexibility, material handling flexibility, programming flexibility). } \\
\text { Marketing flexibility, which includes the following types of flexibility: (product flexibility, volume } \\
\text { flexibility, mix flexibility, expansion flexibility). } \\
\text { Infrastructural flexibility, which is the flexibility of the organization. }\end{array}$ \\
\hline Narasimhan and Das ${ }^{[25]}$ & $\begin{array}{l}\text { Operational flexibilities (Machine /shop level): This level consists of the following dimensions (equipment } \\
\text { flexibility, material flexibility, routing flexibility, material handling system, program flexibility). } \\
\text { Tactical flexibilities (Plant level): This level consists of the following dimensions (mix flexibility, volume } \\
\text { flexibility, modification flexibility) } \\
\text { Strategic flexibilities (Firm level): This level consists of two dimensions (New product flexibility, Market/ } \\
\text { delivery flexibility). }\end{array}$ \\
\hline $\mathrm{Oke}^{[28]}$ & $\begin{array}{l}\text { New product flexibility: The ability of a manufacturing system to introduce and manufacture new parts and } \\
\text { products }{ }^{[27]} \text {. } \\
\text { Mix flexibility: The ability of the organization to produce different combinations of products economically and } \\
\text { effectively, given a certain capacity }{ }^{[43]} \text {. } \\
\text { Volume flexibility: The ability of the organization to operate at various batch sizes and/or at different } \\
\text { production output levels economically and effectively }{ }^{[43]} \text {. }\end{array}$ \\
\hline
\end{tabular}

It means adaptiveness, responsiveness, agility, resilience, freedom, compromise, openness, adjustment, versatility, customization, elasticity and so on ${ }^{[36]}$. Therefore, flexibility is classified into different categories using different perspectives. A summary of flexibility classifications is provided in Table 1.

The benefits of flexibility: Reviewing the literature on flexibility ${ }^{[14,20,21,23,29,34,39,40]}$ shows that flexibility offers the following benefits to organizations:

- Increasing sales volume, or preventing sales being lost, by making products more competitive (e.g. delivery, price, quality, product, specification);

- Increasing selling price, without a corresponding increase in product cost or loss of sales (e.g. charging a premium price for improved delivery);

- Eliminating unprofitable orders (e.g. by improving quotation system);

- Reduced inventory levels;

- Reducing product delivery times;

- Improving the reliability of delivery promises;

- Improving the ability to match product specification to customer needs;

- Reduction in scrap and rework that comes from eliminating set-ups;

- Improving delivery performance;

- Having a greater ability to cope with uncertainty;

- Managing manufacturing schedule fluctuations;

- Applying Just In Time (JIT)purchasing;
- Managing demand volatility, demand seasonality and forecast accuracy;

- Improving supplier responsiveness;

- Affecting positively a firm's performance;

- Enabling firms to fully explore various product definitions and ideas; and

- Allowing firms to gather customers' feedback and investigate design feasibility.

The need for flexibility: With regard to the role of flexibility in enabling organizations to cope with uncertainties, De Toni and Tonchia ${ }^{[10]}$ argue that flexibility is needed due to the following factors (products: wideness of the range, number of parts; manufacturing processes planning and control, the variability of demand, shorter life cycles of products and technologies, increased customization, and shorter delivery times). Gupta and Somers ${ }^{[15]}$ emphasize that companies need more flexibility when they decide to compete in the high end of markets on the one hand and to respond to competitors' actions on the other hand. Similarly, Wainwright and Bateman ${ }^{[40]}$ argue that the need for flexibility is emphasized in response to changes associated with compression of product life cycles, increased product diversity and a reduction in customer lead times. A need for wider product scopes and the trend towards shorter product life cycles are some factors that make flexibility a top priority issue in manufacturing strategy ${ }^{[27]}$. Similarly, ${ }^{[19]}$ referring to ${ }^{[8,10 \text {, }}$ ${ }^{13]}$, Corrêa ${ }^{[9]}$ argue that the need for flexibility is linked to two groups of factors namely: 
- Market- related factors: examples on these factors include (increased product diversity, short product life cycle, the variability of the demand, shorter life-cycles of the products and technologies, wide range of products, increased customization and shorter delivery times).

- Manufacturing- related factors: examples on these factors include (focused manufacturing, manufacturing technology innovation, unexpected competitors, uncertainty with respect to machine downtime, uncertainty of whether the material input meets the standards of the process, changes with respect to delivery times of raw materials and variations in workforce).

Organizational objectives: Objectives refer to what an organisation seeks to achieve through its existence and operation; it answers to the question, why are we in business? Organisations may have a variety of different objectives such as: growth in revenues, higher dividends, attractive economic value added, a bigger market share, high quality, lower costs relative to key competitors, and higher levels of customer satisfaction than rival (Thompson and Strickland ${ }^{[38]}$. According to Steiner ${ }^{[35]}$ preparing objectives should consider (suitability, measurability, feasibility, acceptance, flexibility, motivation, clearness, people participation and purposive ness). In this context, Berson and Avolio $^{[2]}$ referring to Gillen ${ }^{[13]}$ state that "The effectiveness of strategic goal implementation depends on how well leaders in an organization perceive and clarify the goals, translate them into more specific goals tied to respective units and then encourage an open learning environment to facilitate the pursuit and successful completion of the goals". However, organizational objectives should be linked to a firm's strategy. Therefore, Managers are responsible for directing followers towards achieving organizational objectives in consistent with organization's mission, vision, strategy and goals ${ }^{[2]}$. In summary, objectives serve organizations through ${ }^{[26]}$.

- Providing managers with clear targets which they can study towards

- Deciding priorities by focusing on the desired ends and results

- Building commitment through encouraging employees to commit themselves to the ends of the organization

- Serving as measuring rods against which choices can be made

- Serving as measuring rods against which against which performance is appraised
- Influencing motivation as the clear and achievable objectives can offer a sense of personal achievement to the individual.

Bennett $^{[1]}$ gives the following examples of operational objectives:

- Increasing the volume sales

- Increasing the market shares of various market segments

- Minimizing the production cost

- Maximizing the plant utilization

- Generating large cash flows

- Expansion of working capital

- Improvements in credit control (for example: reducing the average period needed to collect a debt)

Similarly, Berson and Avolio, 2004 $4^{[2]}$ give the following example on strategic objectives:

- Emphasize cost reduction;

- Changing union agreements;

- Preserving technological advantages;

- Realizing new business environment;

- Moving into new markets and more clients;

- Developing innovative products as opposed to obsolete products;

- Move into new markets and more clients;

- Moving to foreign markets;

- Increasing shareholders' wealth;

- Being a leading company;

- Developing, producing and supplying new products;

- Improving work processes; and

- Becoming profitable in the short- term to achieve long-term goals.

Achieving the above objectives is the responsibility of leaders at all levels in organizations. This notion is supported by Cannella and Monroe ${ }^{[5]}$ in which they indicated that Leaders at all levels are responsible for the dissemination of strategic organizational goals, as well as for convincing their constituents to effectively implement those goals

Previous empirical works: However, the model of this study was developed after reviewing many previous empirical works on flexibility. Table 2 shows the major finding resulted from recent previous empirical works related to flexibility. 
Table 2: results of selected empirical studies on flexibility

\begin{tabular}{|c|c|}
\hline Author(s)/ researcher(s) & Summary of the major finding, results, and conclusions \\
\hline Jack and Raturi ${ }^{[18]}$ & Volume flexibility has a positive impact on financial and delivery performance of firms. \\
\hline Zhang et al. ${ }^{[43]}$ & $\begin{array}{l}\text { Volume flexibility and mix flexibility have significant, positive, and direct impacts on the customer satisfaction. } \\
\text { Machine flexibility, labor flexibility, material handling flexibility, and routing flexibility have a significant, } \\
\text { positive indirect impact on customer satisfaction. }\end{array}$ \\
\hline Chang et al. ${ }^{[6]}$ & $\begin{array}{l}\text { New product flexibility has marginal significant effect on sales growth. Both product mix and volume flexibility } \\
\text { have a positive impact on sales growth. New product, product mix and volume flexibility lead to improve } \\
\text { business performance. }\end{array}$ \\
\hline Zhang et al. ${ }^{[41]}$ & $\begin{array}{l}\text { Physical distribution flexibility and demand management flexibility have significant, positive, and direct } \\
\text { impacts on the customer satisfaction. }\end{array}$ \\
\hline Jack and Powers ${ }^{[17]}$ & Volume flexible capability had a direct effect (positive and significant) on customer-related performance \\
\hline Chang et al. ${ }^{[7]}$ & $\begin{array}{l}\text { Autonomy, innovativeness, risk-taking and proactiveness have significant positive effects on new product } \\
\text { flexibility. }\end{array}$ \\
\hline Verdu'-Jover et al. ${ }^{[39]}$ & $\begin{array}{l}\text { A good fit in the level of managerial flexibility and a high degree of financial flexibility are related to better } \\
\text { organizational performance. }\end{array}$ \\
\hline
\end{tabular}

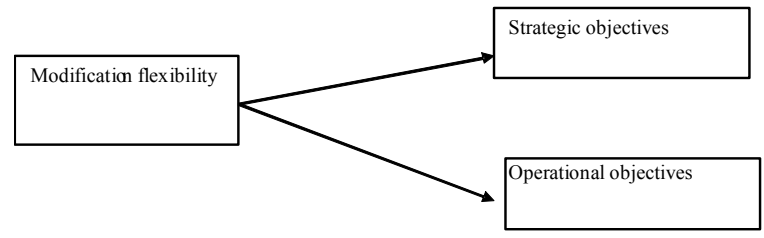

Fig. 1: Research model

\section{MATERIALS AND METHODS}

Research model: After reviewing the literature the gaps were identified and the suggested directions for future research in the previous study were considered. For example, Boyle ${ }^{[3]}$ promote that future research should empirically focus on testing and developing a more complete and rigorous list of best management practices that are required for implementing manufacturing flexibility. The research model depicted in Fig. 1 is used to predict the anticipated relationships between (modification flexibility) and the achievement of organizational objectives.

\section{Operational definitions of the research variables}

Independent variable: Considering the research objectives and question mentioned above the operational definitions of the research constructs are as follows:

\section{Modification flexibility (independent variable)}

- The ability of the manufacturing process to customize products through minor design modifications $^{[25]}$. Customization of product means the quick response to deal with customers' needs and wants to satisfy all levels of customer expectations.

- The ability to modify features of pre-existing products $^{[7]}$.
Organizational objectives (dependent variables): According to Bennett ${ }^{[1]}$, objectives can be strategic, tactical, or operational. The focus of this research was on the strategic and operational objectives. These constructs are operationally defined below:

Strategic objectives: represent a managerial commitment to achieving specific performance targets within a specific time frame- they are a call for results than connect directly to the company's strategic vision and core values ${ }^{[38]}$. Examples on these objectives according to ${ }^{[2]}$ include (becoming the market leader in a particular field, improving industrial relations within the enterprise, higher level of customer satisfaction than rivals, higher product quality than rivals, growth in revenue, superior customer service and wider geographic coverage than rivals)

Operational objectives imply the short term day-today or week-to-week, aims of a factory or department. The many reasons highlighting the operational objectives for implementing flexible manufacturing systems include: reduction in work-in-progress or inventory or both, reduction in lead time; reduction in labor, improved quality, improved machine utilization, reduction in (overall) costs, raised output of productivity, reduction in defects or scrap, reduction in absenteeism; reduction in breakdowns and optimum use of floor area ${ }^{[22]}$. Bennett ${ }^{[1]}$ consider the following objectives under the category of operational objectives (increasing the volume sales, increasing the market shares of various market segments, minimizing the production cost, maximizing the plant utilization, generating large cash flows and expansion of working capital).

Research hypotheses: The research model depicted in Fig. 1 is designed to predict the anticipated relationships between modification flexibility and 
organizational objectives. The model included one independent variable (modification flexibility) and two dependent variables (strategic objectives and operational objectives). Therefore, this research is designed to test two hypotheses to address its objectives. The two hypotheses can be formulated as follows:

H1: Modification flexibility has a positive impact on the achievement of strategic objectives.

$\mathrm{H} 2$ : Modification flexibility has a positive impact on the achievement of operational objectives.

Research population and sample: The data of interest in this study are responses from executives with titles of Director, Vice-President, Operations or Production Manager and Marketing Manager. Jordanian manufacturing companies that are classified as public shareholding companies at Amman Stock Exchange Market were chosen as the targeted population for this research because the industrial sector is more relevant and clearly reflects the constructs of this research. The entire population, which consisted of 91 industrial companies that are classified at Amman Stock Exchange Market as industrial shareholding companies according to its report for the year 2007, was targeted as the sample of this research. The questionnaire was accompanied by a covering letter explaining the research objectives. The participants were asked to complete the questionnaires, which were picked up later. The main survey consisted of 240 questionnaires targeted 60 manufacturing companies participated in the research survey out of 91 . The completed and usable questionnaires were 162 represented a response rate of $67.5 \%$. The responding firms cover a wide range of manufacturing activities including electronics, engineering products, electric, chemical, textiles, leathers and clothing, glass and ceramic, engineering and constructions, mining and extraction, food and beverages, study and cartoon and pharmaceutical and medical products.

Data collection methods and measurement of the research constructs: Data collection consisted of a questionnaire designed to test the model and a delivery and collection questionnaire method was used in distributing and collecting the questionnaires to ensure a high response rate and to take the advantages of personal contact since this method enhances respondent participation. The questionnaire format was highly structured where all of its questions were fixedresponse alternative questions that required the respondents to select from responses which are located by using five point Likert scales. All of the measurement scales used in this research were based on existing research. Assuring the validity and reliability measures requires supported literature to validate the measurement scales used for operationalsing the research constructs. For measuring modification flexibility, the measurement scales and indexes were adapted from the previous study of: $:^{[15,20,21,31,34]}$ Sethi and Sethi, 1990, Gupta and Somers, 1996, Kara et al., 2002, Koste et al., 2004, Salvador, et al., 2007). Organizational objectives constructs were measured using measurement scales used by Lim ${ }^{[22]}$, Bennett ${ }^{[1]}$.

Data analysis: A reliability test was carried out using Cronbach's alpha, which measures the internal consistency of a construct. The recommended minimum acceptable limit of reliability "alpha" for this measure is $0.60^{[33]}$. The results can be seen in Table 3 for all $\alpha$ values constructs. The Table shows that all the constructs have passed the reliability test where all $\alpha$ values have exceeded the recommended minimum value of Cronbach's alpha.

Concerning the validity procedures and to ensure that the criteria of questionnaire construction and pretesting were met, time and effort were devoted towards design, layout and wording of the questionnaire used in this research. As a result, the survey instrument was pre-tested with executives and academic experts who were asked to review the questionnaire for readability, ambiguity, completeness and to insure that the questions asked are appropriate for tapping the research constructs $^{[33]}$. This process has led to several minor changes, which were made prior to generating the final version of questionnaire.

Table 3: Reliability analysis of the research constructs

\begin{tabular}{lll}
\hline Construct & Construct type & $\alpha$-value \\
\hline Modification flexibility & Independent & 0.969 \\
Strategic objectives & Dependent 0. & 0.726 \\
Operational objectives & Dependent 0. & 0.798 \\
\hline
\end{tabular}

Table 4: Descriptive statistics of the research constructs

\begin{tabular}{lllll}
\hline Construct & Mean & $\begin{array}{l}\text { Standard } \\
\text { deviation }\end{array}$ & Skewness & Kurtosis \\
\hline Modification flexibility & 3.52 & .71 & .076 & -.913 \\
Operational objectives & 3.92 & .31 & -.607 & .222 \\
Strategic objectives & 3.25 & .67 & -.694 & .070 \\
\hline
\end{tabular}

Preliminary data analysis and descriptive analysis: Descriptive statistics were used to determine the relative importance for modification flexibility in achieving organizational objectives. Table 4 shows the means, standard deviations and values of skewness and kurtosis for the research constructs.

Hypothesis testing: Simple regression analysis was carried out to test the research hypotheses. Simple regression identifies how much of the variance in the dependent variable will be explained when a variable is 
able to predict a particular outcome. Using simple regression analysis is subject to normality of the data. Therefore, the values of skewness and kurtosis (measures of distribution) for each variable are reported in Table 4 in order to check variables for assumptions of normality. In general a skewness/kurtosis value greater than one indicates a distribution that differs significantly from a normal symmetric distribution ${ }^{[16]}$. Skewness and kurtosis values within the range of -1 to +1 indicate an acceptable range. Reviewing the descriptive statistics presented in Table 4 shows that skewness and kurtosis values for all variables fall within the acceptable range which means that the data is normally distributed.

As indicated in Table 5, the results of F-ratio show that the regression model is significant at $\mathrm{p}<0.001$. Fratio is 53.156 and 317.676 for $\mathrm{H} 1$ and $\mathrm{H} 2$ respectively. Therefore, we can conclude that the regression model predicts strategic objectives construct and operational objectives construct significantly well. In other words, modification flexibility has the ability to predict the outcome variables (dependent variables: strategic objectives construct and operational objectives construct).

\section{RESULTS}

The results emerged from the data analysis have shown that:

1. Jordanian manufacturing companies have successfully and partially achieved their organizational objectives.

2. Operational objectives construct is ranked with an average of 3.92 while strategic objectives construct is ranked with an average of 3.25 .

3. Modification flexibility is weighted with an average of 3.52 .

4. The coefficient of determination $\mathrm{R}^{2}$ which predicts the relationship between the independent variable (modification flexibility) and the dependent variables (strategic objectives construct and operational objectives construct) is equal to 0.249 and 0.665 respectively. In other words, this result revealed that: $24.9 \%$ of the total variance in the dependent variable (strategic objectives construct) is accounted for by the independent variablemodification flexibility and $66.5 \%$ of the total variance in the dependent variable (operational objectives construct) is accounted for by the independent variable-modification flexibility.

5. Modification flexibility impacts on achieving each of strategic objectives and operational objectives.

\section{DISCUSSION}

As shown in Table 4, the results of descriptive statistics give us the indication that operational objectives are easier to be achieved compared to strategic objectives. This result can be justified based on the fact that strategic objectives are long term ones and they are associated with a higher degree of uncertainty and therefore, they need more capabilities and flexibility to be achieved. Considering the results of hypothesis testing summarized in Table 6, the decision was made to accept the research hypotheses (HI and H2) mentioned again in Table 6. Thus, the hypothesized relationship between modification flexibility and organizational objectives are supported by the results of data analysis. However, the results of hypothesis $\mathrm{H} 1$ and $\mathrm{H} 2$ are consistent with the literature on operations strategy and manufacturing flexibility. Modification flexibility according to Kara et al., ${ }^{[20]}$ is the ability of a process to make functional changes in the product. It is a result of uncertainty as to which particular attributes customers may want. These changes may arise at the beginning of the life cycle for a standardized product or throughout the life cycle for a product that can be customized ${ }^{[11]}$. It is believed that operational goals are affected by changes associated with product life cycle which is becoming shorter due to the rapid changes in business environment.

Therefore, Narasimhan and Das ${ }^{[24]}$ concluded that modification flexibility should be utilized when coping with changes result from short product life cycle. It was noted that that the coefficient of determination $R^{2}$ which explains the total variance in the dependent variable (operational objectives construct) which is equal to 0.665 is higher than the coefficient of determination $R^{2}$ which explains the total variance in the dependent variable (strategic objectives construct) which is equal to 0.249 . This result means that the modification flexibility construct is correlated with operational objectives construct more than its correlation with strategic objectives construct. This result may be justified since employees are more involved in setting and implementing operational objectives compared to strategic objectives.

Therefore, the need for modification flexibility is more emphasized when planning operational objectives rather than strategic objectives. However, this result is consistent with the literature; for example, in the study done by Samuelsson et al. ${ }^{[32]}$, a gap was found between operational and strategic perspectives at the lower and middle organizational levels: lower management ranked criteria that corresponded to strategic objectives lower than did the middle management. They refer this gap to the lack of incentives for aligning with the strategic objectives. If there were no incentives, lower managers tended to prioritize operational criteria. 
Table 5: Model summary and ANOVA: $\mathrm{H} 1$ and $\mathrm{H} 2$

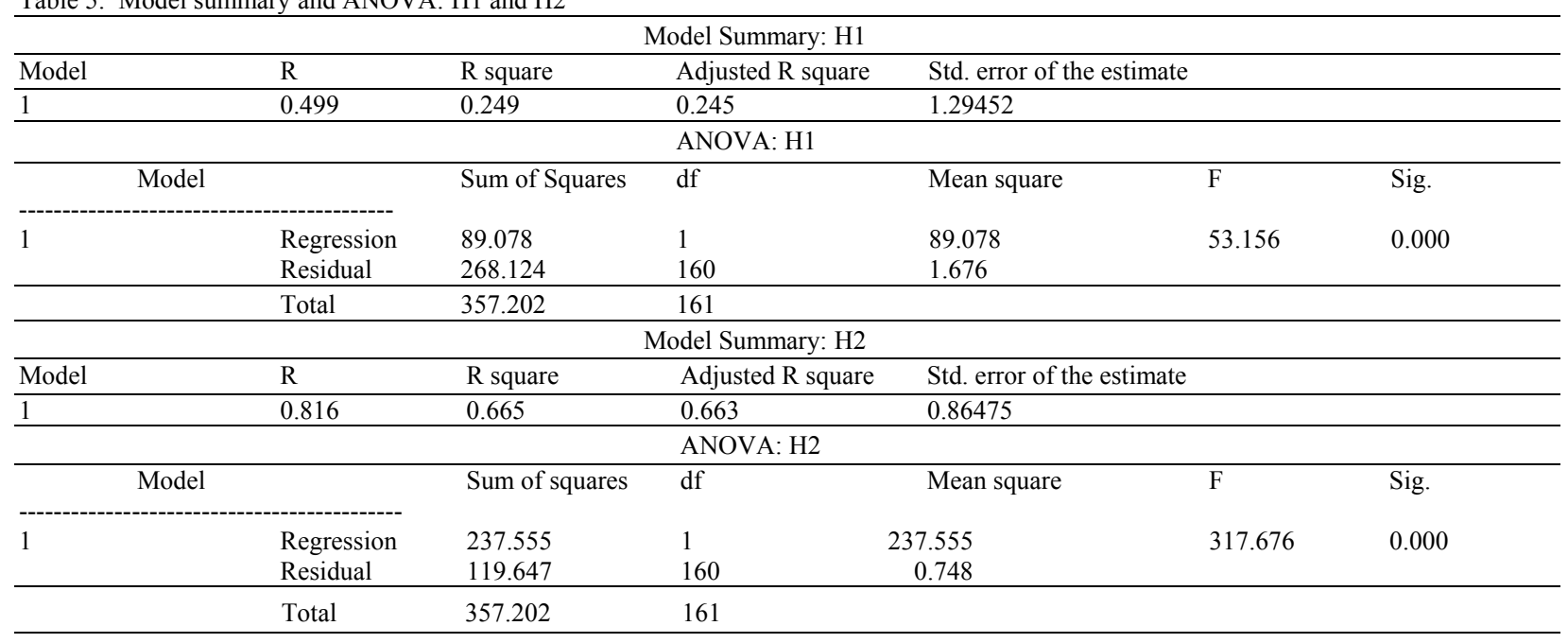

Table 6: Summary of the research hypotheses (H1and H2) and their results

\begin{tabular}{|c|c|c|c|c|}
\hline Hypothesis & Beta & t-value & Sig & Comment \\
\hline $\begin{array}{l}\text { H1: Modification } \\
\text { Flexibility has a } \\
\text { positive impact } \\
\text { on the achievement } \\
\text { of strategic objectives. } \\
\text { H2: Modification }\end{array}$ & 0.499 & 7.291 & 0.000 & Accept \\
\hline $\begin{array}{l}\text { Flexibility } \\
\text { has a positive impact } \\
\text { on the achievement of } \\
\text { operational objectives. }\end{array}$ & 0.816 & 17.823 & 0.000 & Accept \\
\hline
\end{tabular}

\section{CONCLUSION}

The overall results of the empirical investigation have supported the research model presented in Fig. 1. The results indicated significant impact of modification flexibility on achieving the operational and strategic objectives. Therefore, this conclusion leads us to believe that modification flexibility should be considered when planning and implementing the organizational objectives of a firm.

Managerial implications: The findings of this research have the following practical implications for managers:

- Managers are encouraged to use modification flexibility in planning, setting and achieving the organizational objectives.

- Organizational objectives can be achieved and carried out based on different dimensions of flexibility. Modification flexibility is an important one of them.
- Modification flexibility can be used for managing and planning the operations strategy of a firm in the short and long run.

Limitations and directions for future research: Several limitations in this study should be noted. The study has not taken into consideration the effect of the moderating and intervening variables (such as company size, business unit, organizational structure, industry type) on the relationships between modification flexibility and organizational objectives. In addition, there was a lack of local and regional empirical studies previously conducted in the fields of this study on Jordan or Arab business environments. The sample was also limited to the Jordanian manufacturing companies classified in Amman Stock Exchange Market as public industrial shareholding companies. Thus, it is not representative of global industry and therefore the findings are not generalisable as the research excluded the Jordanian manufacturing companies that are not classified in Amman Stock Exchange Market. These limitations should be viewed as opportunities for future research. This study has made a significant contribution, as it is one of the first attempts that aimed at empirically testing the impact of modification flexibility on organizational objectives. The following directions are suggested for further research:

- Conducting empirical studies about the need for modification flexibility at strategic, operational and tactical levels in a firm.

- Conducting empirical studies about the role of modification flexibility on gaining the competitive advantage of a firm and improving its performance. 
- Investigating the role of the intervening and moderating variables (i.e. company size, organizational level, industry type) on the relationship between modification flexibility and organizational objectives.

\section{REFERENCE}

1. Bennett, R., 1999., Corporate Strategy. $2^{\text {nd }}$ ed. Pitman Publishing. pp. 19-29. ISBN-0: 0333970047

2. Berson, Y. and B., Avolio, 2004. Transformational leadership and the dissemination of organizational goals: A case study of a telecommunication firm., The Leadership Quarterly 15 (5): 625-646. DOI:10.1016/j.leaqua.2004.07.003

3. Boyle, T.A., 2006. Towards best management practices for implementing manufacturing flexibility. Journal of Manufacturing Technology $\begin{array}{llll}\text { Management. } 17 & \text { (1): 6-21. DOI: }\end{array}$ 10.1108/17410380610639470

4. Buzacott, J.A., 1982. The fundamental of flexibility in manufacturing systems. Proceedings of $1^{\text {st }}$ International Conference on FMS, Brighton, pp.13-22. ISSN: 1465-4652

5. Cannella, A. A., \& Monroe, M. J., 1997, Contrasting perspectives on strategic leaders: Toward a more realistic view of top managers. Journal of Management, 23 (3): 213-238. DOI: $10.1177 / 014920639702300302$

6. Chang, S., Lin, R., Chang, F., and Chen, R., 2007. Achieving manufacturing flexibility through entrepreneurial orientation. Industrial Management and Data Systems., 107 (7): 9971017. DOI.10.1108/02635570710816711

7. Chang, S., Yang C., Cheng H., and Sheu.C., 2003. Manufacturing flexibility and business strategy: An empirical study of small and medium sized firms. International Journal of Production Economics. 83 (1): 13-26. DOI.10.1016/S0925-5273 (02)00263-3

8. Chen, I.J., Calantone, R.J., and Chung, C.H., 1992. The marketing-manufacturing interface and manufacturing flexibility. Omega. 20 (4): 431-443. ISSN 0305-0483

9. Corrêa, H.L. 1994. Linking flexibility: Uncertainty and Variability in Manufacturing Systems. Ashgate Publishing Co. Aldershot, England. ISBN-10: 1856286207

10. De Toni, A., and Tonchia, S., 1998. Manufacturing flexibility: A literature review. International Journal of Production research., 36 (6): 1587-1617.DOI: 10.1080/002075498193183
11. Gerwin, D., 1987. An agenda for research on the flexibility of manufacturing processes. International Journal of Operations and Production Management., 7 (1): 38-49. DOI.10.1108/eb054784

12. Gerwin, D., 1993. Manufacturing flexibility: A strategic perspective. Management Science. 39 (4): 395-410. ISSN:0025-1909

13. Gillen, D., 2000. The leadership of learning: The core process of strategy implementation. In P. Flood, T. Dromgoole, S. J. Caroll, \& L. Gorman (Eds.), Managing strategy implementation (pp. 138-151). Oxford, UK7 Blackwell. ISBN: 9780631217664

14. Gupta, Y.P. and Somers, T.M., 1992. The measurement of manufacturing flexibility. European Journal of Operation Research., 60 (2): 166-182. ISSN 0377-2217

15. Gupta, Y.P. and Somers, T.M., 1996. Business strategy, manufacturing flexibility, and organizational performance relationships: A path analysis approach. Production and Operations Management., 5. (3): 204-233. ISSN: 1937-5956

16. Hair, J., Anderson, R., Tatham, R. and Black, W., 1998. Multivariate Data Analysis. $5^{\text {th }}$ ed., Upper Saddle River, NJ: Prentice-Hall., pp. 3586. ISBN: 0-13-930587-4

17. Jack, E. and Powers, T., 2006. Managerial perceptions on volume flexible strategies and performance in health care services. Management Research News. 29 (5): 228-241. DOI. 10.1108/01409170610674374

18. Jack, E., and Raturi, A., 2002. Source of volume flexibility and their impact on performance. Journal of Operations Management., 20 (5): 519548. DOI.10.1016/S0272-6963 (01) 00079-1

19. Kara, S. and Kayis, B., 2004. Manufacturing flexibility and variability: an overview. Journal of Manufacturing Technology Management. 15 (6):466-478. DOI.10.1108/17410380410547870

20. Kara, S., Kayis, B., and O'Kane S., 2002. The role of human factors in flexibility management: a survey. Human Factors and Ergonomics in Manufacturing.12(1):75-119.DOI.10.1002/hfm. 10004

21. Koste, L., Malhotra, M., and Sharma, S., 2004. Measuring dimensions of manufacturing flexibility. Journal of Operations Management., 22(2):171-196. DOI.10.1016/j.jom.2004.01.001

22. Lim, S.H., 1987. Flexible manufacturing systems and manufacturing flexibility in the United Kingdom. International Journal of Operations and Production Management., 7 (6): 44-54. DOI.10.1108/eb054807 
23. Ling-yee, L. and Ogunmokun, G., 2008. An empirical study of manufacturing flexibility of exporting firms in China: How do strategic and organizational contexts matter?" Industrial Marketing Management. 37 (8): 738-751. DOI.10.1016/j.indmarman.2007.05.007

24. Narasimhan, R. and Das, A., 1999. Manufacturing agility and supply chain management practices. Production and Inventory Management Journal. 40 (1): 4-10. ISSN:0897-8336

25. Narasimhan, R. and Das, A., 2000. An empirical examination of sourcing's role in developing manufacturing flexibilities. International Journal of Production Research., 38 ( 4): 875-893. DOI: $10.1080 / 002075400189202$

26. Naylor, J. 1996. Operations Management. Pitman Publishing, London. PP. 78-110. ISBN 07121-1054-2-7121-1054-2

27. Nilsson, C. and Nordahl, H., 1995. Making manufacturing flexibility operational-part2: A framework. Integrated Manufacturing Systems., 6 (1): 5-11. DOI: 10.1108/09576069510082084

28. Oke, A., 2005. A framework for analyzing manufacturing flexibility. International Journal of Operations and Production Management., 22 (10): DOI.10.1108/01443570510619482

29. Pagell, M. and Krause, D., 2004. Re-exploring the relationship between flexibility and the external environment. Journal of Operations Management., 21 (6): 629-649. DOI. 10.10.1016/j.jom.2003.11.002.

30. Primrose, P.L., and Verter, V., 1996. Do companies need to measure their production flexibility. International Journal of Operations and Production Management., 6 (6): 4-11. DOI. 10.1108/01443579610119054

31. Salvador, F., Rungtusanatham, M., Forza, C., and Trentin, A., 2007. Mix flexibility and volume flexibility in a build-to-order environment: synergies and trade-offs. International Journal of Operations and Production Management., 27 (11): 1173-1191. DOI. 10.1108/01443570710830584

32. Samuelsson, P., Ekendahl, P., and Ekev ä rn, P., 2006. Operational perspectives on performance: what is prioritized in a large construction company? Measuring Business Excellence. 10 (1); 36-47. DOI: 10. 1108/1368304061065220

33. Sekaran, U., 1992. Research Methods for Business: A Skill Building Approach. Second Edition, New York: John Wiley and Sons. pp. 274-308. ISBN: 978-0-471-20366-7
34. Sethi, A.K. and Sethi, S.P., 1990. Flexibility in manufacturing: A survey. International Journal of Flexible Manufacturing Systems. 2 (4): 289328. DOI. 10.1007/BF00186471

35. Steiner, G. 1979. Strategic Planning: What Every Manager Should Know, Free Press, New York, NY., pp. 163-168. ISBN:0-02-931110-1

36. Sushil., 2001. Demythifying flexibility. Management Decision. 39 (10): 860-865. DOI.10.1108/00251740110402355

37. Tachizawa, E. and Thomsen, C., 2007. Drivers and sources of supply flexibility: an exploratory study. International Journal of Operations and Production Management. 27 (10): 1115-1136. DOI.10.1108/01443570710820657

38. Thompson. A. A. and Strickland, A. J. 2003. Strategic Management: Concepts and Cases, $13^{\text {th }}$ edition, McGraw-Hill Irwin., pp. 1-29. ISBN: 007-244371-5

39. Verdu'-Jover, A, Go'mez-Gras, J. and Llore'ns-Montes, F. 2008. Exploring managerial flexibility: determinants and performance implications. Industrial Management and Data Systems, 108 (1): 7086. DOI.10.1108/02635570810844098

40. Wainwright, C.E.R. and Bateman, N., 1997. Auditing system flexibility in the context of manufacturing strategy information. Logistics Information Management. 10 (4): 167-177. DOI.10.1108/09600039810248145

41. Zhang, Q., Vonderembse , M., and Lim, J., 2005. Logistics flexibility and its impact on customer satisfaction. The International Journal of Logistics. $16 \quad$ (1): 71-95. DOI.10.1108/09574090510617367

42. Zhang, Q., Vonderembse, M., and Cao, M., 2008. Product concept and prototype flexibility in manufacturing: Implications for customer satisfaction, European Journal of Operational Research., $194 \quad$ (1): $143-154$. DOI.10.1016/j.ejor.2007.12.013

43. Zhang, Q., Vonderembse, M., and Lim, J. 2002. Manufacturing flexibility: Defining and analyzing relationships among competence, capability, and customer satisfaction", Journal of Operations Management., 21 (2): 173-191. DOI.10.1016/S0272-6963 (02)00067-0 